\title{
Islamic Ethics and Genomics: Mapping the Collective Deliberations of Muslim Religious Scholars and Biomedical Scientists
}

\author{
Mohammed Ghaly ${ }^{1}$
}

When the Human Genome Project (HGP) took off in 1990, experts in the field were aware of the fact that this scientific megaproject would generate ethical questions and conundrums that should be taken seriously. ${ }^{2}$ So, an ethical arm for the HGP was established, namely the Ethical, Legal and Social Implications (ELSI) program. Five percent of the total HGP budget was dedicated to the ELSI program, making the project one of the largest-ever investments in bioethics research. Unlike most of the previous bioethics research, the ELSI program worked in conjunction with the scientific research activities. Rather than waiting for the results of the scientific research and their possible ethical implications, the HGP leadership decided to anticipate, identify, analyze and address the ethical concerns early on. The HGP example of conflating genomics with ethics concurrently became a to-be-followed model, sometimes with critical remarks, for subsequent genomics projects conducted elsewhere. Major research funding organizations, such as the Wellcome Trust and the UK Economic and Social Research Council, have also set a financial plan for research on genomics-related ethical issues (Rabinow and Bennett 2009, 106;

1 Professor of Islam and Biomedical Ethics, Research Center for Islamic Legislation \& Ethics (CILE), College of Islamic Studies, Hamad Bin Khalifa University, Doha, Qatar, mghaly@ hbku.edu.qa

2 This research was made possible by the NPRP grant "Indigenizing Genomics in the Gulf Region (IGGR): The Missing Islamic Bioethical Discourse", no. NPRP8-162o-6-057 from the Qatar National Research Fund, a member of The Qatar Foundation. The statements made herein are solely the responsibility of the author. I hereby submit my due thanks to the Research Assistant of the project, Mrs. Shaimaa Moustafa, and Dr. P.S. Van Koningsveld (Leiden University) who helped editing earlier versions of this chapter.

(C) MOHAMMED GHALY, 2019 | DOI:10.1163/9789004392137_004

This is an open access chapter distributed under the terms of the prevailing CC-BY-NC License at the time of publication. 
Jasanoff 2011, 7; Boddington 2012, 24-25; Kaye 2012, 673-674; Green et al 2015, 31; Morrison, Dickenson and Lee 2016, 1-6).

Despite its considerable richness and potential usefulness for addressing many issues, the ELSI program and its resulting literature were less beneficial to the religious, not to mention particularly Islamic, perspectives. The governing moral landscape of the ELSI programs was dominantly, and sometimes even exclusively, secular in nature. The ELSI of the HGP and its subsequent versions in Western countries did not even include the word "religion" in the title. This made the ELSI literature considerably poor when it comes to incorporating the perspective of religious ethics; a shortcoming that was highlighted by those who critically reviewed the ELSI work (ELSI Research Planning and Evaluation Group 200o, ii, iii, 3, 19, C2, C3).

\section{A Genomics in the Age of Collective Reasoning (al-ijtihād al-jamāc $\bar{\imath})$}

Like the ELSI programs, the Islamic discussions on the ethical implications of the HGP and genomics in general were initiated before the completion of the scientific research. In fact, these discussions started even before the establishment of the national genome projects led by Qatar and Saudi Arabia. Furthermore, the ELSI literature was used in these discussions, especially by Muslim biomedical scientists ${ }^{3}$, as background information featuring the key ethical dilemmas and the main benefits and risks involved. However, unlike the ELSI work, Islamic ethical deliberations on genomics had their own distinct language, style, modes of reasoning and prioritization of the key ethical concerns, which are all steeped in the religious tradition of Islam and are couched under the key term of independent and critical reasoning $(i j t i h \bar{a} d){ }^{4}$ The crux of ijtihād within the context of genomics is that Muslim religious scholars ${ }^{5}$ approach the foundational texts of Islam (viz. Quran and Sunna) and

3 "Muslim biomedical scientists" and, less frequently, "physicians" are used as generic terms referring to the participants in the collective deliberations on bioethical issues, with background in biomedical sciences.

4 See for instance the resolution adopted by the Islamic Fiqh Academy (IFA), affiliated with the Muslim World League on ijtihād, issued in January 1985 . The resolution stressed the necessity of practicing ijtihād, especially in its collective form, in order to address the modern complex issues from an Islamic perspective. See Ba'dānī 2016, 92-94.

5 "Muslim religious scholars" and, less frequently, "jurists" are used in this chapter as generic terms comprising the broad spectrum of those with expertise in Islamic sciences. Sometimes, the term "jurists" is used to make reference to the experts in the discipline of Islamic jurisprudence in particular. Whenever the latter is the case, I indicate this clearly in the text. 
their hermeneutics in order to show what these texts would imply with regards to such novel bioethical questions. As for genomics in particular, some Muslim religious scholars gave their own individual insights, through the mechanism of individual reasoning (al-ijtihād al-fardī). Nonetheless, the main and rigorous discussions took the form of interdisciplinary discourse between Muslim religious scholars and biomedical scientists, through the mechanism of collective reasoning (al-ijtihād al-jamā $\bar{\imath})$.

In its individual form, the whole process of $i j t i h \bar{a} d$, starting from developing the right perception (tașawwur șahịh) of the issue at hand, which was termed elsewhere the "informative" component, and ending by determining the right action to be taken, which was named elsewhere the "normative" component, is traditionally managed by an individual religious scholar, more particularly the jurist (al-faqih) (Ghaly 2015, 287-288). Within this type of ijtihäd, which has dominated throughout the history of the Islamic tradition, the jurist can, in principle consult with specialists in fields like medicine or engineering in order to improve the informative component of their ijtihäd. However, the whole process remains individual in character in the sense that it is one jurist who is responsible for managing this process and, more importantly, seen as the individual issuer of the fatwa $(m u f t \bar{t})$. On the other hand, the collective reasoning (al-ijtihäd al-jamā $\bar{\imath})$, as its very name suggests, is collaborative in nature and thus is not based on one single jurist but a group of individuals who collaboratively manage the whole process. This collaboration can take the form of consulting non-figh specialists, like physicians or scientists, in order to improve the abovementioned informative component or consulting other religious scholars to make sure that the normative component and the resulting fatwa are not flawed. Conventionally speaking, biomedical scientists would be responsible for developing the right perception (tașawwur șahịh), or the informative element of the ijtihād process, by explaining, say, what genomics exactly is about to the religious scholars. On their turn, religious scholars will make use of this scientific explanation of genomics in order to construe the religious perspectives, or the normative element of the ijtihād process, in conformity with this right perception. However, we shall see below that the process of al-ijtihād al-jamā $\bar{\imath}$, especially as far as genomics is concerned, is highly dialectical and the arguments and counterarguments go frequently back and forth among these diverse groups of participants. For instance, we will see how biomedical scientists contribute to the discussions on the normative part of the ijtihād process.

Historically, al-ijtihād al-jamã $\bar{\imath}$ has its roots back in the early history of the Islamic tradition, where some would date it back to the lifetime of the Prophet of Islam and the subsequent period of the Rightly-Guided Caliphs, but it 
always remained less widespread than the individual ijtihād and was only sporadically practiced (Raysūnī 2010, 59-64). In the twentieth century, the need for reviving the mechanism of al-ijtihäd al-jamā $\bar{\imath}$ in general, and particularly when it relates to novel issues, as it is the case in the field of biomedical ethics, was repetitively voiced by both religious scholars and biomedical scientists.

Employing al-ijtihād al-jamā $\bar{\imath}$, its advocates argued, was indispensable to properly address the complex ethical questions raised by astounding technological advancements, which transformed the nature of many aspects of people's lives. By the beginning of the $198 \mathrm{os}$, the mechanism of al-ijtihād al-jamā $\bar{\imath}$ started to take an institutionalized form. The Islamic Organization for Medical Sciences (IOMS), based in Kuwait, which was established in 1981 and assumed its current name in 1984, has been the most active and all their symposia exclusively focused on bioethical issues. Shortly before getting its current name, particularly in 1983, the IOMS initiated the series of al-Isläm wa al-mushkilät al-țibbiyya al-mu'āṣira (Islam and Contemporary Medical Issues), which incorporated a long list of publications on various topics, including genomics. The IOMS coordinates with two other institutions whose interest in bioethics is rather occasional, as part of their broad interest in the role of Sharia in the modern world. One of these two institutions is the Islamic Fiqh Academy (IFA), established in 1977, which is affiliated with the Muslim World League and based in Mecca, Saudi Arabia. The other institution is the International Islamic Fiqh Academy (IIFA), established in 1981, based in Jeddah, Saudi Arabia, and affiliated with the Organization of Islamic Cooperation (Ghaly 2015, 292-294).

It is to be noted that the gravity shift to the collective ijtihād did not terminate its individual form. The conclusions resulting from ijtihad, whether collective or individual, are not religiously binding and, in principle, they can be challenged by another collective ijtihäd or even by individual scholars. Individual ijtihäd creates an opportunity for the religious scholar (mujtahid) to contemplate and reflect upon the issue at hand and the related textual references and contextual aspects, making it more prone to error. Alternatively, collective ijtihād is more restrictive because each participant in this process has to take into consideration the other participants' thoughts; this makes it less susceptible that flawed conclusions are collectively adopted. In spite of this, collective ijtihäd can only materialize and flourish when the participating individuals develop their own individual $i j t i h \bar{a} d$ and then constructively share the resulting conclusions with their peers. Therefore, these two forms of $\ddot{j} t i h \bar{a} d$ are not necessarily mutually exclusive to each other (Raysūnī 2010, 59). This holds true for the case of genomics as well. Although collective ijtihäd dominated the discussions, some Muslim religious scholars made their own individual contri- 
butions to this topic (e.g. Khādimī 2003, 7-48; Kan'ān 2003, 68-101; Idrīs 2003, 22-25; Khādimī 2004, 59-76; 'Uthmān 2009; Ghaly 2016, 34).

During the 199os, the decade of the HGP, the mechanism of al-ijtihād aljamā $\bar{\imath}$ was already institutionalized more than a decade ago. Using this mechanism for addressing bioethical issues started to be the norm, and a certain legacy started to take form. Before its symposium was held in October 1998, which addressed the ethical issues of genomics, the abovementioned series "Islam and Contemporary Medical Issues" of the IOMS had already organized more than ten interdisciplinary symposia in which Muslim religious scholars and biomedical scientists collaboratively deliberated on a wide range of topics like abortion, beginning and end of human life, organ donation, AIDS, cloning, ...etc. This is also the case for the other two institutions, namely IFA and IIFA, where the mechanism of collective ijtiha $\bar{d}$ was adopted to discuss many bioethical discussions, including assisted reproductive technologies, blood transfusion, human milk banks, organ transplantation, and sex reassignment surgery (Ba'dānī 2016, 199-210, 222, 223, 476-485, 491).

The almost two-decade experience of adopting the mechanism of collective ijtihād in the field of bioethics, with considerable success, made approaching genomics through this mechanism, an indisputable choice. Collective ijtihäd was accepted as a recognized and credible mechanism for tackling modern bioethical questions, where they were seen as too complex to be addressed by those specialized in either religious sciences or biomedical sciences alone. If this is valid to issues like human milk banking and assisted reproductive technologies, then it applies in a much stronger sense to the case of genomics. This explains the frequency of collective discussions on genomics and Islamic ethics. Besides the aforementioned IOMS, IFA and IIFA, other institutions also used the mechanism of al-ijtihäd al-jamā $\bar{\imath}$ to address the ethical aspects of genomics, as to be outlined below.

\section{Interdisciplinary Deliberations}

To my knowledge, the seminar "Ethical Implications of Modern Researches in Genetics" (Al-In'ikāsāt al-akhlāqiyya li al-abḥāth al-mutaqddima fì 'ilm alwirātha), organized by the Faculty of Science at the University of Qatar during the period 13-15 February 1993, was the first to examine the Human Genome Project and the prospective field of genomics from an Islamic ethical perspective. The proceedings of the seminar were published in both Arabic and English (ISESCO 1993; İsiskū 1993). ${ }^{6}$ During the period 13-15 October 1998, the

6 I hereby submit my due thanks to Dr. Khalid Al-Ali, the former director of the Foundation Program at Qatar University and Chairperson of the UNESCO World Commission on the Ethics of Scientific Knowledge and Technology (COMEST). He thankfully made me aware of this 
IOMS organized the symposium "Genetics, Genetic Engineering, Human Genome and Gene Therapy: An Islamic Perspective" (Al-Wirātha wa al-handasa al-wirāthiyya wa al-jīnūm al-basharì wa al-ilāj al-jīnī: Ru'ya Islāmiyya), henceforth the 1998 symposium. The proceedings of this symposium and its final recommendations remain the most influential document, and subsequent collective deliberations highly depend on them. In its eleventh session held during the period 14-19 November 1998, the IIFA discussed the recommendations of the 1998 symposium, but deferred the resolution to another future meeting because the participants felt the need for conducting further study and research. During the period 5-10 January 2002, the IFA held its sixteenth session, which discussed among other issues, the possible fields in which the DNA fingerprinting can be employed. The seventh resolution of this session made a cursory reference to the human genome, stressing that it cannot be dealt with as a commodity in whatever way. The Faculty of Sharia and Law at the United Arab Emirates University organized the conference "Genetic Engineering between Sharia and Law" (Al-Handasa al-wiräthiyya bayna al-Sharìa wa al-qānūn) during the period 5-7 May 2002, whose proceedings were published in four dense volumes (Kulliyyat 2002). During the period 6-9 February 2006, the IOMS organized an international Seminar on "Human Genetic and Reproductive Technologies: Comparing Religious and Secular Perspectives". The recommendations of this seminar included a section entitled "Declaration of Principles", which paraphrased specific segments of the recommendations adopted during the 1998 symposium. The attempt here was seemingly to augment the support for these principles by engaging secular and religious voices from outside the Islamic tradition (Awadi and Gendy 2008, 1173-75). The second edition of the conference series, "Pan Arab Human Genetics", organized by the Dubai-based Centre for Arab Genomic Studies (CAGS), included a Public Forum on "The Ethical Perspectives of Human Genetic Applications in the Arab World", which was held on 20 November 2007. Besides the submitted papers, the forum issued the "Dubai Declaration", adopting some standpoints related to genomics. A few years later, and during its twentieth session held during the period 13-18 September 2012, the IIFA rekindled the discussions on the recommendations of the 1998 symposium, but, yet again, the resolution was deferred to a future meeting. During the period 23-25 February 2013, a specialized seminar took place in Jeddah that was jointly organized by the IIFA and IOMS. After an extensive journey of almost 15 years, the recommendations of the 1998

seminar and provided me with its publications. In the following sections, I will make use of the Arabic and English editions of this seminar depending on the original text of submitted articles. 
symposium were endorsed, with few modifications and additional points, by the IIFA during its twenty-first session, held on 18-22 November 2013. ${ }^{7}$

In addition to hosting the conference held in 1993, Qatar also hosted some of the recent expert meetings during which both biomedical scientists and religious scholars deliberated on genomics. In collaboration with other Qatar-based institutions, the Research Center for Islamic Legislation \& Ethics (CILE) convened two activities. On 2 October 2014, a public seminar entitled "Islamic Ethics in the Era of Genomics" was organized in collaboration with the then Qatar Supreme Council of Health (SCH), now Ministry of Public Health. As part of its 2016 edition, the Doha-based World Innovative Summit for Health (WISH) collaborated with CILE in organizing a Research Forum on "Genomics in the Gulf Region and Islamic Ethics", which focused on the ethical management of incidental findings. The study produced by this Research Forum was published in both Arabic and English (Ghaly 2016; Ghaly 2016a). Finally, CILE organized the international seminar "Islamic Ethics and the Genome Question" during the period 3-5 April 2017, the proceedings of which are published in this volume.

The analyses provided in this chapter are based on a careful review of the abovementioned deliberations, including some of the unpublished papers which were presented during these interdisciplinary meetings. However, the proceedings of the abovementioned 1998 symposium will serve as the main reference in this chapter. This choice has to do with the seminal role played by the proceedings of the seminar in the overall Islamic ethical discussions on genomics. References to other meetings and publications of individual scholars will be made whenever necessary to show certain similarities or differences between the individual and collective forms of $\ddot{j} t i h \bar{a} d$.

\section{Explanatory Remarks}

Before delving into the detailed analysis of the deliberations on genomics and Islamic ethics, three explanatory remarks are due in order to understand the analysis to follow:

The first remark deals with the themes and issues discussed in the abovementioned meetings and conferences. The Human Genome Project (HGP) and the field of genomics in general occupied a central place in the discussions. However, almost all of these meetings also discussed many other issues, some of which are closely related to genomics, whereas others are of less relevance

7 I hereby submit my due thanks to Dr. Muhammad 'Alī al-Bār who provided me with some of the papers presented to this session. It is to be noted that the proceedings of this session have not been published yet. 
or may be completely unrelated. In the following section, I endeavored to keep the focus on the field of genomics and the HGP, but it was almost impossible to avoid references to issues related to other themes, especially genetics, genetic engineering, gene therapy and the like. Because of the nature of the discussions during these meetings and conferences, it was sometimes impossible to make clear distinctions between the points and arguments related to genomics and those related to genetic engineering, genetic counseling, etc.

The second remark refers to the geographical scope of these deliberations. The abovementioned meetings and conferences were almost all transnational in character. In other words, an institution based in Qatar or Kuwait, for example could host the event, but the pool of participants usually represented the diversity of the Muslim world in general, and also sometimes Muslims living as religious minorities worldwide. However, one notices that almost all events took place in the Gulf region, which witnessed the key genomics projects in the Muslim world. Furthermore, the countries that hosted many of these events, especially Qatar and Saudi Arabia, also established national genome projects, both in December 2013. ${ }^{8}$ This indicates that the conflation of genomics and ethics, which we have seen in the HGP, continued in the initiatives taking place in the Muslim world.

The third remark relates to one of the typical difficulties of practicing ïtihäd by religious scholars in the field of bioethics, namely the difficulty of grasping the technicalities of scientific information, especially in complex disciplines like genetics, genetic engineering and genomics. Among other reasons, Mainstream Muslim religious scholars hardly have any background information about this type of knowledge or even access to relevant first-hand or primary sources (Ghaly 2015, 288-289). The deliberations on genetic engineering, genomics and the HGP demonstrated how difficult the interdisciplinary communication was between biomedical scientists and religious scholars. In the 1998 symposium, the IOMS president, 'Abd al-Raḥmān al-'Awaḍi, recognized that the participating religious scholars had difficulties understanding the lecture given by the Syrian biomedical scientist Hānī Rizq ${ }^{9}$ and asked that scientific information should be presented in a simpler and clearer way'10 (Jundī 1998,

8 For more information about genomics projects and initiatives in the Gulf region, see Ghaly 2016, 7-15.

9 After the symposium, Rizq wrote two key Arabic books that were meant to introduce scientific information, especially in the field of genetics, to the general educated public. Two of his books, the latest of which was on human genome and ethics, (Rizq 2003; Rizq 2007) received awards from the Kuwait Foundation for the Advancement of Sciences (KFAS). The published proceedings of this symposium do not include a paper written by Dr. Rizq. However, Dr. Muhammad 'Alī al-Bār, in his published paper in this symposium, spoke 
195-196). After the first session of the symposium, the IOMS secretary general assistant, Ahmad al-Jundī, mentioned that he had received many proposals suggesting that another biomedical scientist, namely Hassān Ḥathūt, should present his paper earlier than it was planned because of his ability to simplify scientific information. Eventually this happened to clearly save the situation and improve the level of communication with religious scholars (Jundī 1998, 266). Hathūt himself recognized this problem and criticized the participating physicians for being sometimes inclined to "stretch their muscles" by presenting complex information inaccessible to the religious scholars. Conversely, Hathūt explained, physicians have to be aware that their exclusive mission is to communicate specialist information to the jurists. Whatever they do, which does not contribute to fulfilling this mission, is nothing but useless effort (Jundī 1998, 321). Ḥathūu's presentation was well received and some jurists commended him for his ability to communicate complex information in an easy and accessible way (Jundī 1998, 297, 301, 302, 303). However, some religious scholars, like the Saudi Nāșir al-Maymān and the Syrian Muhammad Rawwās Qal'ajī, continued complaining about this problem and demanded that biomedical scientists should use an easier and more accessible language (Jundī 1998, 315, 353). During subsequent discussions within the International Islamic Fiqh Academy (IIFA), al-Bār spoke about the same problem when he commented on what happened during the 1998 symposium. He said that after about a one-hour lecture given by Rizq, the participating jurists said, "Translate to us what he said. We did not understand anything" (IIFA 1998, 11/1112).

Additionally, both religious scholars and biomedical scientists objected the imprecise or vague character of some information presented by biomedical scientists. For instance, there were wide discrepancies in the papers submitted by the scientists about the number of genes in the human body, the accuracy of statistics mentioned by some papers, the right terminology to be used, the very definition of genetic engineering and whether cloning can be part of it, etc. (Jundī 1998, 299, 306, 308-310, 311, 317, 318-319, 684). This can be due to the fact that some of these scientists were not geneticists by specialization,

about a certain paper that Dr. Rizq submitted to the symposium and that it included some inaccurate information (Bār 1998, 622). So, it is possible that al-Awadīi is referring here to a paper which did not find its way to publication, maybe because of its inaccessibility to the religious scholars or because of including mistaken information. However, Dr. Rizq presented two papers written by other scientists, respectively the Saudi Ṣālih al-Kurayyim and the Moroccan Muhammad al-Yashawī, because they were not available for presenting their papers on the first day of the seminar. So, it is possible that al-Awadī here is referring to the presentation that Riqz gave on behalf of these two authors. It is to be noted that al-Yashawì could join the discussions later (Jundī 1998, 1012). 
like the internist Muhammad al-Bār, the gynecologist Ḥassān Ḥathūu and the pharmacist Ahmad al-Jundī. Another possible reason for the confusion around specific scientific information can also be traced to the fact that most of the papers went back to the 199os when the HGP was still in progress and many issues were unsettled among scientists worldwide. The papers written in the 1990s, by both biomedical scientists and religious scholars, continued to be the main reference for all subsequent discussions with hardly any new updates that could have had tangible impact on the interdisciplinary discussions. ${ }^{11} \mathrm{~A}$ third possible reason is that some religious scholars were simply looking for the impossible, namely having clear-cut (qat $i \bar{\imath}$ information all the time. The very nature of an emerging and rapidly developing field like genomics makes it sometimes difficult to have stable and certain information which cannot be challenged by further research. One of the clear examples in this regard is calculating the exact number of genes in the human genome. This issue has always remained controversial, and one of the latest publications shows that scientists still cannot agree on how many genes are in the human genome and sometimes even on how to define a gene (Willyard 2018).

Below, we will notice that this problem made some religious scholars feel that they missed the right perception (tasawwur șahịh) of some issues related to genomics. Additionally, the absence of specific scientific information or the feeling that such information is not clear-cut or conclusive enough makes it difficult for the religious scholar to make a rigorous weighing between possible benefits (mașālih) and expected harms (mafāsid), or, in bioethical terms, the so-called benefit-risk assessment. In his comment on the draft of the final recommendations of the 1998 symposium, the UK-based physician 'Abd al-Majīd Qațma said that the possible harms of a technology, like gene therapy cannot be known for sure, and this uncertainty will continue for a long time. That is why, he argued, it is better to wait until we are 100\% sure (Jundī 1998, 1005). Another related problem was determining the person(s) who has/have the authority to decide what is beneficial and what is harmful. The Syrian religious

As an example, one can check one of the newest papers in this regard, namely the paper of Ahmad al-Jundī, which he presented during the eleventh session held by the IIFA in September 2012 and then again, but in a much more concise form, in the specialized seminar jointly organized by the IIFA and IOMS in February 2013 (Jundī 2013). Despite some updates included in the paper, we hardly see any influence resulting in modifying or updating the final recommendations adopted by the 1998 symposium. Strikingly enough, some of the ethical issues which emerged after the completion of the Human Genome Project and later dominated the ethical deliberations on genomics worldwide, like the management of incidental findings, hardly received any attention in the parallel Islamic bioethical discussions. See Ghaly 2016, 3 o. 
scholar, Ahmad al-Kurdī, argued that the referential authority in toto should be given to the academics and scholars, each in liaison with one's specialization (Kurdì 1998, 241). On the other hand, the Tunisian religious scholar, Mukhtār al-Sallāmī, argued that such an opinion is factually isolating the jurists from the reasoning process. However, al-Sallāmī added, deliberations on these issues should remain interdisciplinary by facilitating communication between specialists in human genome and genetic engineering on one hand and jurists on the other hand. In his comment on al-Sallāmī's critique, al-Kurdì said that this type of interaction between the two groups is actually what he meant (Jundī 1998, 249, 264). All the preceding difficulties did problematize the process of $i j t i h \bar{a} d$ to the extent that some religious scholars became even reluctant to express an Islamic ethical position in general.

\section{B Framing Genomics: Two Main Approaches}

The participants in the abovementioned deliberations agreed that the world is currently witnessing one of its biggest scientific revolutions ever, especially in fields like genetics and genetic engineering. To them, the Human Genome Project (HGP) is at the very heart of this revolution. In the symposium held in Qatar in 1993, the Pakistani molecular biologist, Anwar Nasim, said that genetic engineering and its related disciplines are advancing at an unparalleled tempo, which was never seen throughout the history of biology. As for the HGP in particular, he said "the current effort to map and sequence the entire human genome is, without doubt, the most significant and ambitious undertaking of biological research in modem times" (Nasim 1993, 63, 70). In his opening speech of the 1998 symposium, the IOMS secretary general assistant, Ahmad al-Jundī, said that what has been achieved during the last fifty years is equivalent to multiple folds of what humanity could achieve since the beginning of creation. He enumerated giant steps made by the relatively new field of genetics, which are increasingly narrowing the gap between imagination and reality.12 Similar statements were also expressed by Muhammad al-Mursī Zahra (the then dean of the Faculty of Sharia at the United Arab Emirates University) in his intro-

Al-Jundì dedicated a number of pages to outline the key achievements made by genetics and genetic engineering. He gave examples like using electronic microscopes and computers to fathom out the cell and unearth its secrets, producing human insulin (laboratory-grown synthetic insulin, which mimics insulin in humans) to replace the animal/ porcine insulin, trying to overcome the scarcity of human organs for transplantation by producing genetically-engineered porcine hearts so that they will not be rejected when transplanted in human bodies, and DNA fingerprinting (Jundī 1998a, 24-26). 
duction to the voluminous publication on genetic engineering between Sharia and law (Kulliyyat 2002, 5-6). Speaking about the Human Genome Project (HGP), al-Jundi said that this is the most serious issue in the field of genetic engineering. Despite possible risks related to autonomy and privacy that must be taken into consideration, al-Jundī argued that the potential of the HGP will go beyond mapping the genes and discovering mutations to eventually open the door for studying the reasons behind these mutations, and how to fix them through gene therapy (Jundī 1998a, 23-28). Recognizing the new scientific revolution and the crucial role played by the HGP therein was a recurrent theme during the 1998 symposium and was repeatedly voiced by many others outside the symposium (ISESCO 1993, 263; Nasim 1993, 63, 70; Anees, 1993, 78; Ḥaffār 1993, 123-137; Jundī 1998, 68, 70, 211, 274, 736, 797, 1024; Hatḥūt 1998, 274; Maymān 1998, 797-798). Later on, we will notice that this agreed-upon fact among the participants would have an impact on framing genomics. It would lead to the expression of some theologically tinted explanations of how it was possible that scientific communities based in the West could achieve such a revolution despite their carelessness and negligence of religious guidance and its associated values, whereas Muslim countries have hardly made any substantial contribution in this regard.

Beyond this point of agreement, one can notice two different approaches towards genomics and related issues. Each approach is comprised of two main aspects; one is theological and theoretical in nature, while the other focuses on juristic and practical elements. In other words, each approach is premised on certain theological assumptions, which are further fleshed out and phrased in a juristic and a practical position towards the field of genomics, as epitomized by the Human Genome Project (HGP). Both religious scholars and biomedical scientists contributed to each approach. As explained in the first section of this chapter, the conventional boundaries between the tasks assigned to biomedical scientists and those entrusted to religious scholars were blurred in these discussions. Below, we will see that the biomedical scientists did not restrict their contribution to providing scientific information only, i.e., the informative component of the ijtihād process. On various occasions, they additionally contributed to the normative component by giving their insights on theological and juristic aspects of genomics. It is to be noted, however, that the contribution of the religious scholars to the informative component remained quite minimal.

\section{$1 \quad$ Precaution-Inclined Approach}

In a bid to explain the abovementioned point with regards to the scientific revolution, its exclusive Western leadership and the absence of Muslim countries' 
contribution, this approach made use of a quasi-determinist, and typically Ash'ar $\overline{1}^{13}$, theological framing. This theological framing was mainly expounded by the Kuwaiti religious scholar, 'Ajīl al-Nashmī, in his paper submitted to the abovementioned 1998 symposium. He started his paper with lamenting the deplorable state of scientific research in the Muslim world and expressing his frustration that today's Muslims abandoned the leading role that their ancestors ever played in advancing sciences. Furthermore, al-Nashmì asked Muslims to stick to the firm belief that all modern scientific advancements in cutting-edge fields like genetic engineering, the HGP and gene therapy, could only materialize because this was God's will. He explained that it was only God who provided these Western scientists with the necessary power and capabilities to accomplish these achievements, and had He willed otherwise, they would never have been able to achieve anything. However, the results of these scientific ventures belong to these scientists' own acts for which they remain responsible, and God gave them the ability to do these acts by way of testing $(i b t i l \vec{a})$ His creatures to see how they will behave (Nashmī 1998,545-547). This is a typically Ash'arī position which explains the seemingly problematic phenomena in life by trying to strike a balance between two points. On one hand, there is stress on God's omnipotence and that nothing can take place in the universe against His will. On the other hand, there is recognition of a certain degree of individuals' freedom to act so that humans remain responsible for their acts by way of acquisition (kasb). Within such a position, there is little space left for detailed rational argumentations about the theodicy or the possible wisdom behind such problematic phenomena (Ghaly 2010, 24-26).

Against the background of this quasi-determinist theological framing, alNashmī moved to the juristic practical aspects of this approach where he gives an overall preference for a casuistic approach. He argued that Muslims should deal with the applications of these cutting-edge scientific ventures and try to evaluate the benefits and harms of each application through of the lens of Sharia. This means that each application should have its separate religious ruling (hukm shar $\bar{\imath})$. As for the Human Genome Project (HGP) in particular, al-Nashmī argued that it is in principle a noble project, or -again reflecting his inclination towards precaution- this is how it should be. Al-Nashmī held the notion that the overall juristic framework, which governs the HGP and its possible applications, is the framework of the five higher objectives of Sharia (maqāssid al-Sharīāa), namely safeguarding religion, one's life, intellect, prog-

The analysis provided by al-Nashmī here is clearly inspired and influenced by the Ash'arī theory of acquisition (kasb). For more information about this theory, see Abrahamov 1989 . 
eny and property. According to al-Nashmī, the HGP relates more to the third objective, namely the preservation of progeny (nasl) whose integrity should always be safeguarded against any possible manipulation or misuse. If this is the case, al-Nashmi elaborated, then the default rule concerning the HGP and its applications should be that all related actions are in principle prohibited unless there are strong arguments to justify an exception to this default rule (Nashmī 1998, 548-550).

Strikingly enough, the position premised on prohibition as the governing rule is not the mainstream position in Islamic jurisprudence (figh), where humans are generally permitted to make use of what God created unless there is a scriptural reference or compelling reason to move it from the realm of original permissibility (al-barāa al-așliyya) to prohibition. This mainstream position, supported by the majority of Muslim jurists, is based on Quranic verses like "He is the One Who created everything in the earth for you" (Q. o2:29) and "And He has subjected to you whatever is in the heavens and whatever is on the earth" (Q. 45:13). Jurists couched this position in the well-known legal maxim, "permissibility is the original state of things (al-aṣl fi al-ashyä al-ibāha)" (Wizārat 1983-2006, 1/130, 18/74-75, 103). What made a contemporary jurist like al-Nashmī transfer genomics from this mainstream original permissibility to the realm of original prohibition? Besides the technical juristic reason mentioned by al-Nashmī himself, viz. the relevance of genomics to the objective of safeguarding progeny which dictates more cautiousness, there are other possible reasons related to the scientific and socio-political context of the Muslim world in which the field of genomics was born.

Integral to this approach is the idea that Muslims should be aware of the possible religious perils of this scientific revolution, despite its possible beneficial advancements in fields like genetics and genomics. In various places in al-Nashmì's paper, one easily observes his deep distrust of the Western scientific institutions, which dominate the field of genomics, when it comes to the commitment to religious values. Unsurprisingly, al-Nashmī explained, many of the results of modern scientific research are not in conformity with the Islamic Sharia because the leaders in these fields are not guided by religious values and are mainly motivated by material interest and personal desire (haw $\bar{a})$. According to him, the absence of divine guidance, as communicated through revealed scriptures, will inevitably lead to misguidedness and deviation from the straight path. He added that this misguidedness got even normalized to the extent that many Muslims believe that this [absence of religious guidance in scientific research activities] is the norm to be followed (Nashmī 1998, 46). Similar concerns were shared by other participants like Ahmad al-Jundī, the IOMS secretary general assistant and the late Egyptian physician and former 
Minister of Health, Ibrāhīm Badrān (d. 2015) (Jundī 1998, 100, 102). In his opening speech for the 1998 symposium, al-Jundì said that one should be alert that most of the scientific researchers have no religion to abide by except their own scientific imagination (Jundī 1998a, 29). Al-'Awaḍī, al-Jundī and the Mauritanian religious scholar, 'Abd Allāh Bin Bayya, referred to the example of scientific research on nuclear energy, which eventually led to catastrophic repercussions by manufacturing the atomic bomb and using it twice. Bin Bayya expressed his fear that biology could move into the same direction that nuclear energy had walked through before, and thus may eventually lead to self-destruction of humanity. ${ }^{14}$ In his paper submitted to the 1998 symposium, Ahmad al-Jundī quoted Oppenheimer (d. 1967), the scientific director of the Manhattan Project, to say, "Now and now only, science has fallen into sin" (al-än wa al-änfaqațaqa'a al-ilm fí al-khațỉa $)^{15}$ (Jundì 1998, 30). In his paper submitted to the specialized seminar jointly organized by the IIFA and IOMS in 2013, al-Jundi suggested that a link between this notorious example and the Human Genome Project (HGP) is not too far-fetched. He recalled the history of the US Department of Energy, the main catalyst of the HGP, which goes back to the Manhattan Project and its role in developing the atomic bomb during World War II (Jundī 1998a, 30; Jundī 1998, 194, 197; Jundī 2013, 13).

It seems that the perceived tension between current scientific research activities and religious values also influenced some Muslim religious scholars while weighing possible harms against expected benefits in order to judge the Human Genome Project (HGP) and the field of genomics in general. Ben Bayya spoke about estimations stating that $30 \%$ of beneficial resources on earth was exhausted in the twentieth century (Jundī 1998, 197). As for the HGP in particular, al-Nashmì dedicated less than one page to outline its possible benefits, mainly preventing and treating genetic diseases (Nashmī 1998, 551-

The case of the nuclear bomb was, for these participants, the most glaring example to show how destructive scientific research can be. The Egyptian physician added other examples which show the severity of possible harms that can result from originally good scientific research and technologies. He referred to the advanced means of transportation that cause the death of 5 million people per year; the industrial revolution which left millions of qualified workers without jobs; and the laser that can be transformed into lethal weapons, making people blind before their death. See Jundī 1998, 101.

Oppenheimer's statement has to do with his experience after watching the first atomic bomb test, called Trinity, and naturally with the later atomic bombings of Hiroshima and Nagasaki. It is to be noted that the original statement, "physicists have known sin", is much more nuanced and cautiously formulated than what the Arabic translation given by al-Jundī suggests. According to some, this degree of ambiguity in the phrase was intended by Oppenheimer himself, see (Thorpe 2006, 12, 19o). 
552). However, possible harms and corruptions of the HGP and gene therapy were discussed in about ten pages and divided into three distinct sections, namely technical, ethical and psychosocial harms. As for the technical harms, al-Nashmī spoke about the risk of cancer, or even death, for the individuals who undergo gene therapy. He also added that genetically modified animals might end up developing abnormal genes, which can put human life and the whole environment at risk. As for the psychosocial risks, al-Nashmī held that sequencing genome could lead to genetic discrimination with negative impact on one's profession and family. For instance, when information about the sequenced genome reveals one's susceptibility to serious diseases, he/she can be discriminated against by having difficulties to find a job or even a future marriage partner. Concerning the possible ethical harms, al-Nashmī said that subjecting body- and germ-cells to laboratory tests can, unnecessarily, undermine human dignity in many cases. Usually, the main aim in such cases is gaining money and celebrity rather than conducting proper scientific research. What is even more concerning, al-Nashmī added, is the risk of compromising people's privacy by exposing sensitive information included in their genomes to unauthorized agencies and institutions like insurance companies (Nashmī $1998,555-565)$.

It is clear that a jurist like al-Nashmi feels that he is facing a quite suspicious technological advancement, whose possible harms outweigh its expected benefits, while he himself has no power to control or guide its future course. In such a situation, it is not surprising to resort to the position that everything related to this new advancement is prohibited until it is proven otherwise. According to al-Nashmī, the only exception to be permitted in this regard is gene therapy at the level of body cells rather than germ cells. Al-Nashmī, in line with many other religious scholars, argued that gene therapy falls within the scope of medical treatment $(\operatorname{tad} \bar{a} w \bar{\imath})$, whose benefits of treating diseases are to be recognized from an Islamic perspective. Additionally, within the system of maqāsid al-Sharía, gene therapy is more relevant to the objective of protecting one's life (hifzal-nafs) that generally entails permissiveness rather than safeguarding progeny (hifz al-nasl), which usually dictates more cautiousness (Nashmì 1998, 552-554).

Finally, as part of their inclination to cautiousness, the contributors to this approach were reluctant about whether Muslim countries should play a role in this phase of the ongoing scientific revolution or abstain from contributing. Al-Nashmì explicitly stated that Muslims are helpless in this regard. According to him, scientific research will move forward today or tomorrow, and the stakeholders of this research will completely disregard Muslims who will only have to deal with the new reality imposed upon them. He added that Muslims' 
voices are discounted in this regard, and poor Muslim countries are sometimes even misused as field experiments. Without regaining the scientific and civilizational leadership, al-Nashmī argued, both Muslim jurists and political leaders in Muslim countries will not be in a position to do anything except preparing themselves for the worst possible scenarios by drafting protective religious rulings and ethical safeguards (Nashmī 1998, 545-548, 56o). Al-Nashmìs concerns about the missing role of Muslim countries in this regard were commonly shared by others like Hamdī al-Sayyid, the then head of the Egyptian Medical Syndicate and the Egyptian physician Ibrāhīm Badrān (Jundī 1998, 191, 201). Some of the participants took this position a step further and asked for extreme cautiousness. The Egyptian religious scholar, Muhammad Ra'fat 'Uthmān, argued that experiments in the field of genetic engineering seemed too risky and unsafe. Therefore, moratorium would be a good option. According to him, Muslim scientists would better refrain from participating in this field and let scientists in the West continue the work they started until it becomes certain that the final products are free from ethical concerns and physical harms (Jundī 1998, 247).16 Besides postponing the scientific activity, some religious scholars, like Bin Bayya, also asked for parallel cautiousness when it comes to developing an Islamic ethical position. This certainly relates to the third remark, explained in the first section of this chapter, which elaborated the difficulties of the religious scholars to grasp the scientific technicalities of fields like genetics and genetic engineering. Bin Bayya said that religious scholars are required to issue a fatwa in which the scholar is supposed to deduce what God wants people to do. Bearing in mind this very nature of the fatwa, religious scholars are in need of certainty (yaqin) or preponderant probability (zann ghālib), about available scientific information before stating anything. That is why it will be too early to issue a general fatwa about these advancements in the light of the current state of uncertainty about specific information (Jundī 1998, 256-257). On the other hand, the UK-based physician, 'Abd al-Majīd Qațma ${ }^{17}$, argued that Muslim jurists are not yet ready to give fatwas on these complex issues because they are still not sufficiently aware of the relevant scientific discussions and conferences taking place in the UK and Eu-

16 It seems that the further discussions during the 1998 symposium made 'Uthmān change his mind later and express opinions which are closer to the second approach, outlined below. We see this change clearly in his post-symposium published book on genome ('Uthmān 2009). More details about this change in position will be mentioned below. In any case, this is one of the examples which show how collective reasoning and interdisciplinary deliberations (al-ijtihād al-jamā̄i ) can influence the individual form of $\ddot{j} t i h \bar{a} d$. 1998, 837). 
rope. As for long-term solutions, Qațma proposed that Muslim religious scholars would study medicine, as do some lawyers and physicians in the UK who combine between studying medicine and law (Jundī 1998, 839). The Kuwaiti religious scholar, 'Abd Allāh Muhammad 'Abd Allāh, found that the proposed cautiousness of the jurists when they deal with a brand-new issue, such as genetic engineering, is in line with the ideal practice of early religious scholars. The process can be time consuming, sometimes lasting a year, e.g. by studying and verifying the economic reality, including visiting the actual markets to see how people conclude transactions on the ground, before giving their religious advice (fatwa). That is why, 'Abd Allāh suggested, it might be better if today's jurists would first visit the laboratories and observe in reality what happens there, so that their fatwas would be as precise as possible (Jundī 1998, 259-26o).

\section{2}

\section{Embracement-Inclined Approach}

Contrary to the precaution-inclined approach, this approach responds to the success of the scientific revolution led by Western institutions and the failure of Muslim countries in this regard by giving a different theological framing. The main focus of this theological framing is God's justice and wisdom rather than His omnipotence. It is also more open to rational argumentation about the theodicy where human agency occupies a central place. In certain elements, this approach seemed to bear the spirit of Mu'tazili theology (Ghaly 2010, 26-29).

One of the main advocates of this approach who contributed to its theological framing was the late Egyptian US-based physician, Ḥassān Ḥathūu (d. 2009), a prominent and influential figure in al-ijtihād al-jamā $\bar{\imath}$ deliberations on bioethical issues. In his paper submitted to the 1998 symposium $^{18}$, the first subtitle reads "paradox". In this section, Hathūt spoke about God's wisdom that dictated that humans are uniquely gifted with intellect; their main tool to acquire knowledge. Throughout history, Hathuut explained, humans could employ their intellectual capacities to read the universe and unearth its various secrets, one after the other, to the extent that they could achieve breakthroughs and revolutions. However, some people lagged behind in this human search for, and march to, knowledge because they did not use their intellect as they should have. If they continue to do so, Hathuut added, their deserved fate will be marginalization and exploitation through the other advanced nations (Hathūt 1998, 274). The following section of Ḥathūt's paper was entitled "Man Explores Man (Ta'arruf al-insān 'alā al-insān)", where he introduced the HGP 
as one of the key stations in man's long journey to know oneself. This journey, Ḥathūt explained, started with very basic knowledge about man's external appearance and physical makeup as male or female. As time went by, this knowledge continued to improve and assume complex forms where credit goes to sciences like comparative anatomy, studies exploring the genetic structure of the nucleuses of the cells in human bodies, and later the DNA discovery in 1953 by the two Noble laureates, James Watson and Francis Crick. Hathūt argued that the HGP is reading and exploring the human being at the molecular level. Besides their benefit for improving self-knowledge or enhancing the "know thyself" value, Hathūt explained that genomics and the HGP also contribute to having a better knowledge of life and the universe in general. According to him, the four nucleotides found in DNA, namely Adenine, Thymine, Cytosine and Guanine known with the abbreviation ATCG, are the four letters that compose the language of life (lughat al-hayāh). Here, He continued, that the ATCG plays the same role that dots and dashes do in the telegraph and the figures one and zero do in the computer world (Hathūt 1998, 275-277).

During the further discussions among the biomedical scientists and religious scholars, Hathūt elaborated on this point by quoting the Quranic verse "Say, 'Travel throughout the earth and see how He has originated the creation'. Then God will bring the next life into being. Surely, God has power over everything" (Q. 29:20). Hathūt commented by saying that this is a Quranic command, which applies to the question of genome, genetic engineering and the like (Jundī 1998, 320-321). More Quranic verses in the same spirit were added by the Syrian religious scholar, 'Abd al-Sattār Abū Ghudda, in his paper presented to the same symposium, including "And in your own selves; do you then not behold?" (Q. 51:21) and "Our Lord is He Who gave to each thing its due shape and nature, then guided it aright" (Q. 20:50) ${ }^{19}$. Such scriptural references, Abū Ghudda stated, mean that the whole creation, including the universe and man therein, is governed by consistent and coherent laws (sunan) that can be discovered by human intellect (Abū Ghudda 1998, 573). Against this theological background, the results of the scientific revolution are compatible with God's justice and wisdom in the sense that those who used what God gifted them with, viz. human intellect, and worked relentlessly (Western countries) ended up harvesting good results, while those who fell short of the ideal behaviour in this regard (Muslim countries) lagged behind. Consequently, the existing

19 An extensive list of the Quranic verses, which outline the relationship between man and the universe and urge man to look into the wonders of this universe and discover its secrets, was given by the Moroccan religious scholar, Muhammad al-Rūkī, and the Syrian Aḥmad al-Kurdī. See Rūkī 1998, 218-219; Kurdī 1998, 233-236. 
gap in scientific research between the West and the Muslim world is presented through the lens of human agency not in a deterministic framework where the focus is on accepting the status quo as part of God's will.

As we shall see below, this different theological framing will result in different juristic practical perspectives on various issues. It is true that religious scholars and biomedical scientists, who contributed to this approach, accepted certain points advocated by the precaution-inclined approach like the overall preference to a casuistic or case-by-case approach where each application of these cutting-edge technologies is evaluated on the basis of its overall benefits and harms through of the lens of Sharia. Within the paradigm of the five higher objectives of Sharia (maquassid al-Sharīa), they also agreed that these technologies are more relevant to the objective of safeguarding progeny (nasl) and, to a certain extent, also to protecting one's life (nafs), especially when it has to do with therapeutic applications like gene therapy (Abū Ghudda 1998, 577,579 ). Beyond this, the contributors to the two approaches expressed different viewpoints on many issues, as outlined below.

As for the overall governing rule, which applies to the Human Genome Project (HGP) and generally to fields like genetics and genetic engineering, the contributors to this approach opted for the "original permissibility" (al-barāa $a$ al-așliyya). The Moroccan religious scholar, Muhammad al-Rūkī, extensively spoke about this rule and its application to genetic engineering in plants, animals and also in humans but with a higher degree of cautiousness (Rūkī 1998, 216-225). Abū Ghudda argued that this position, especially when it comes to the HGP, should not be a disputable issue (Abū Ghudda 1998, 578). Abū Ghudda defended the relevance of the position of "original permissibility" to these new technologies by referring to the so-called principle of "scripturally unattested or unregulated benefit" (al-mașlaha al-mursala) which has its roots in the Islamic legal theory. ${ }^{20} \mathrm{Abu}$ Ghudda recalled this principle to argue that unprecedented situations, like the issues relating to genetics and the HGP, which entail recognized benefits but are not declared permissible or otherwise by a direct scriptural evidence, should be judged as permissible. According to him, the principle of al-mașlaha al-mursala is crucial evidence recognized by Sharia (dalīl Shar $\bar{\imath}$ ) when one addresses novel issues (mustajaddāt) (Abū Ghudda 1998, 577).

As for the risk-benefit assessment or weighing expected benefits versus possible harms, the mode of reasoning and the resulting conclusions were both different from the precaution-inclined approach. Reference was made to a point that early Muslim religious scholars reiterated, namely the very nature 
of this life hardly allows for the existence of things that are purely and exclusively beneficial (mașlaha mahda). The normal course of this life is that everything has two inseparable sides, one beneficial, the other harmful. What people should usually do is to weigh between these two sides and see which side is stronger than the other. ${ }^{21}$ As for the Human Genome Project (HGP) and technologies related to fields like genetics and genetic engineering, Abū Ghudda stressed the strength of the expected benefits within the scale of Sharia. According to him, such benefits are not luxuries but would rather fall within the highest degree of benefits, namely the necessities (al-darüriyya $t)$. Instead, he recognized that possible harms should be taken seriously because they can eventually disturb one of the higher objectives of Sharia, namely safeguarding progeny (Abū Ghudda 1998, 577-579). Some religious scholars who participated in these discussions, like the Syrian Muhammad Rawwās Qal'ajī, clearly stated that the argumentation of Abū Ghudda proved to be more convincing than that of al-Nashmī. The Syrian religious scholar, Aḥmad al-Ḥajjīi al-Kurdī, added that al-Nashmī was quite uncharitable when he spoke of the possible harms of the HGP, many of which are not necessarily inevitable (Jundī 1998, 6o1-6o3). On the other hand, Abū Ghudda explained that such harms can be controlled, regulated or at least minimized through the mechanism of Sharia-based determinants (dawābit Shariyya) so that one can make sure that the harms will not eventually override the benefits (Abū Ghudda 1998, 577-579). As the interdisciplinary deliberations during the 1998 symposium proceeded, the Egyptian religious scholar, Muhammad Ra'fat 'Uthmān, despite his conservative opinions expressed by the beginning of the seminar, was convinced that the benefits of the HGP strongly override the possible harms. He tentatively expressed this opinion during the seminar (Jundī 1998, 300-301, 834) but his outspoken opinion was expressed in his book on the genome and DNA, which was published in 2009. For instance, the view that the Human Genome Project (HGP) can eventually lead to genetic discrimination that, for him, is nothing but unjustified fear ('Uthmān 2009, 79-80). On his turn, the Saudi gynecologist, 'Abd Allāh Bāsalāma, made use of the very theological framing presented by al-Nashmī to dispel such fears (Jundī 1998, 254-255). As long as one believes that nothing happens in this universe without God's will, Bāsalāma argued, one should not worry about the fate of humans or even their possible ruin. At the end, humans are God's creatures and He is the One who can protect them. It is God who, one

In order to give credibility for this premise and its rootedness in the Islamic tradition, Abū Ghudda quoted the prominent religious scholar, al-'Izz Ibn 'Abd al-Salām (d. 1263), who wrote one of the most authoritative and influential works related to the concept of mașlaḥa. See Ibn 'Abd al-Salām 1991. 
day, can burn the factories, stop the flow of knowledge and put the whole life to an end (Jundī 1998, 254-255).

The contributors to the embracement-inclined approach shared the concerns raised by their peers in the precaution-inclined approach about the possible risks or harms that can result from the separation between scientific research conducted by Western institutions and the religious values (Abu Ghudda 1998, 577). As the deliberations of the 1998 symposium advanced, however, some of the participants insisted that Western institutions are still committed to strict standards and regulations despite the absence of outspoken commitment to certain religious values. 'Abd al-Majīd Qațma, who already contributed to the first approach, conceded that the situation in countries like the United Kingdom might be much better than that in the Muslim world, thanks to thousands of civil society associations active in raising public awareness (Jundī 1998, 838-839). In his paper submitted to the specialized seminar jointly organized by the IIFA and IOMS in 2013, Ahmad al-Jundī gave a somehow different picture about the relationship between genomics and religion in the Western context. He addressed the case of Francis Collins, the director of the HGP, who was said to be an atheist but then turned to be a believer in God because of his research in this field. After two years of contemplation, al-Jundī added, Collins eventually couched his journey of searching for the truth by saying "I found God in the human genome" (Jundī 2013, 24). Al-Jundì's account of Collins's combination of scientific excellence and belief in God missed a few but important nuances. The overall idea that Collins is a prominent scientist and also a committed believer in God is already attested by his own book, The Language of God, published in 2006. However, the book shows that Collins was already a committed believer before leading the HGP, as he spoke about spending a long afternoon praying in a little chapel, seeking guidance from God whether he should accept the offer of being the HGP director (Collins 2006, 119). Thus, Collins' religious commitment did not arise because of his involvement in the field of genomics in particular, although it is clear that his unique experience with the HGP had a positive impact on his belief in God. Although it is an individual case, such an account of a scientist of the caliber of Collins shows that the situation in the West is not as gloomy as al-Nashmi and his likeminded peers may think and that scientists with commitment to religious values can still play leading roles in a scientific mega-venture like the HGP. However, one should not overstate the impact of this supposed science and faith harmony on the bioethical reasoning even for Collins himself. His aforementioned book was appended with a section on "The Moral Practice of Science and Medicine: Bioethics". Collins argued that religious values could play a role, although limited, in the current bioethical deliberations despite 
possible objections from professional bioethicists (Collins 2006, 235-270). But "I hesitate, however, to advocate very strongly for faith-based bioethics", Collins concluded (Collins 2006, 217).

The above-sketched theological framing, the way the contributors to this approach viewed the risk-benefit assessment and the other related juristic and practical aspects, all paved the way to reach the following positive conclusion; Muslims' contribution to fields like genetics, genetic engineering, gene therapy and the like is not only permissible, but is a collective duty (fard kifāya).Various arguments were advanced to support this conclusion. Contributing to these sciences and related technologies was seen as a positive response to the call of Islam to search for knowledge; whatever knowledge as long as it is beneficial for mankind. Throughout the history of Islamic civilization, Muslims provided significant contributions to science and it is now the turn of today's Muslims to do the same through these emerging fields (Zuhaylī 1998, 776; Kurdī 1998, 240; Khādimī 2004, 61). Furthermore, the applications of these emerging fields are meant to help humans improve their health through preventive or therapeutic techniques, and all of these fall within the scope of medical treatment (tadāw $\bar{l})$, whose knowledge is also a collective duty from an Islamic perspective (Zuhayli 1998, 777). The third key argument dealt with socio-political dimensions. As explained above, the contributors to Islamic bioethical discourse on genomics agreed that this field makes part of an impressive scientific revolution whose resulting technologies will determine the future, and even the fate, of countries worldwide (Jundī 1998, 13, 71, 251; Ḥathūt 1998, 274; Nashmì 1998, 545). The Tunisian religious scholar, Nūr al-Dīn al-Khādimī, spoke about an ongoing civilizational race towards achieving scientific supremacy. Currently, he explained, modern scientific discoveries are under global non-Islamic, sometimes even inhumane, hegemony, which monopolizes the resulting technologies and often deprives Muslim countries from having access to these technologies and their benefits. This context of civilizational competition, al-Khādimī argued, dictates that the whole umma (Muslim nation) is under collective obligation ( fard kifäya) to participate in promising fields like genetics and genomics. Political leaders and scientists, who have the ability to participate in exploring the genome, are even under individual obligation (fard 'ayn) to do so (Khādimì 2004, 63; Khādimī 2007). In this vein, the idea of calling for a moratorium on scientific research in the Muslim world related to promising fields like genetics and genomics was vehemently opposed and seen as considerably harmful for the future of Muslim countries (Jundī 1998, 248, 251, 255, 258,). 


\section{Further Developments}

The two main approaches examined in this chapter, with the associated arguments and counter-arguments and internal agreements and disagreements, both contributed to shaping the Islamic discourse on the Human Genome Project (HGP) and genomics in general, in addition to guiding subsequent onthe-ground developments in some Muslim countries.

As far as the overall framing of the HGP and genomics is concerned, the embracement-inclined approach proved to be more appealing and convincing than the precaution-inclined approach. This is clearly reflected in the final recommendations adopted by the conferences and expert meetings outlined in the first section of this chapter. In its Final Report and Recommendations, the 1993 seminar organized by the Faculty of Science at the University of Qatar spoke highly of the HGP and considered it "the most ambitious scientific project in the history of mankind", stressing that "Muslims should not be idle by-standers in this endeavor but should contribute their share to the study of the human biological heritage and to the study of man's future". Consequently, it called upon rich Islamic countries "to generously fund this research, at a level corresponding to the importance and size of the task, so that Muslims may be present in one of humanity's most delicate enterprises and so that we may benefit from its far-reaching results" (ISESCO 1993, 263; Īsiskū 1993, 360-361). The same tone is reiterated in the final recommendations adopted by the 1998 symposium that was organized by the IOMS. The recommendations made no mention of the quasi-determinist theological framing introduced by the precaution-inclined approach, but adopted the other theological framing proposed by the embracement-inclined approach. The HGP was framed as part of man's quest to know oneself and to explore the laws governing God's creation as implied in Quranic verses, such as: "We will show them Our signs in the universe and within themselves until it becomes clear to them that it is the truth" (Q. 14:53). At the practical juristic level, the position of the embracement-inclined approach was also adopted in these recommendations. The HGP was introduced as an added value to the health and medical sciences in their mission to prevent and treat diseases. Thus, the recommendations concluded, reading the human genome falls within the scope of collective duties in society (Jundī 1998 , 1048). The same recommendations also included a call for Muslim countries to join the field of genetic engineering by establishing research centers whose activities should be in compliance with the Islamic Sharia (Jundī 1998, 1047). ${ }^{22}$ By the end of the conference organized by the Dubai-based Centre for

The exact points outlined in these recommendations were quoted verbatim in the recom- 
Arab Genomic Studies (CAGS) in 2007, the participants issued the so-called Dubai Declaration (Bayān Dubayy). The way the declaration was formulated shows that participating in the field of genomics was no longer a question anymore but a taken-for-granted fact, "Since the Arab World is capable of participating in genome research, there is an urgent need for the formation of national committees where the mission is to define an ethics code for scientific research in each of the Arab countries and, subsequently, to coordinate between them and committees in other States". So, the question to be addressed here is no longer whether these countries should contribute to genomics or not, but rather how their contribution should be regulated from an Islamic ethical and legal perspective (http://www.cags.org.ae/eodubaideclaration. pdf).

The subsequent on-the-ground developments in scientific research, at least in the countries that hosted some of the collective deliberations outlined in this chapter, also proved that the embracement-inclined approach had the upper hand. In December 2013, Qatar and Saudi Arabia declared launching their large-scale national human genome projects, each with a huge budget and strong political support at the governmental level. ${ }^{23}$ Available literature indicates that Islamic ethical deliberations, including those examined in this chapter, helped these projects and the associated biobanks in developing their guidelines. This has to do with the fact that "Islam is the dominant religion in these countries, and it affects people's behavior and influences their positions" (Ghiath et al 2015, 53). As for the Saudi Biobank, the two researchers, Ghiath Alahmad and Kris Dierickx, stated that it was "designed in a manner to respect not only international guidelines and Saudi law but also Islamic values, as outlined by the Saudi Biobank governance document" (Alahmad and Dierickx 2014, 682). The Qatar Biobank does not differ much from the Saudi biobank in this regard. In 2014, the biobank released a booklet entitled A Healthier Future Starts with You, which addressed questions related to the relation between scientific biomedical research and Islamic values. The booklet also indicated that the Qatar Biobank is keen to make all its current and future activities compliant with Islam, in collaboration with the Research Center for Islamic Legislation \& Ethics (CILE) (Qatar Biobank 2014, 12-13). The last conference of the Qatar Genome Program on "Ethics, Regulations, and Best Practices in Genomic Medicine", held on 29-30 April 2018, was jointly organized with CILE,

mendations adopted by the participants in the twenty-first session of the IIFA, which was held in November 2013 (http://www.iifa-aifi.org/2416.html).

23 For an overview of these two projects and parallel developments in other countries, see Ghaly 2016, 7-19. 
which supervised two distinct sessions of the conference dedicated to discussing relevant ethical issues from an Islamic perspective. ${ }^{24}$ The influence of the precaution-inclined approach was most visible in highlighting the urgency of possible risks and harms associated with conducting research within fields like genetics and genomics. The final recommendations adopted by the 1998 symposium and their updated version in 2013 adopted by the IIFA, like many other documents, strongly reflected the fears that this type of biomedical research can violate some Islamic values. The recommendations were included in a relatively short text of about 123 o words. In such a concise text, about ten times the reference was made to the necessity of making sure that all research activities are in compliance with the Islamic Sharia and its core values. In support of this argument, we quote phrases like "No research, therapy or diagnosis related to someone's gene or genome can be undertaken unless a rigorous assessment is conducted beforehand in order to measure the potential risks and benefits associated with these activities, in compliance with the provisions of Sharia" and "It is not permissible to use the genome in a harmful way or in any way that violates the Islamic Sharia" (Jundī 1998, 1046; http://www.iifa-aifi.org/2416.html). Despite such frequent references to the significance of abiding by the so-called Sharia-based determinants (dawābit Shar'iyya), unfortunately the final recommendations were usually ambiguous about what exactly these determinants are. However, individual scholars who contributed to these Islamic bioethical deliberations have been trying to clarify some of these dawäbit on specific topics like gene therapy, genetic testing, genetic counseling, DNA fingerprinting or profiling and genetically modified organisms (GMOs) (Jundī 1998, 6-10).

\section{Concluding Remarks}

In the bestseller The Language of God, the acclaimed scientist and director of the Human Genome Project, Francis Collins, held that ethical dilemmas associated with advances in genomics and related fields should not be left to the scientists alone to speculate. Although they have a critical role to play in the deliberations on such dilemmas, scientists' perspectives should be espoused with a wide variety of other perspectives at the table (Collins 2006, 270-271).

24 To attract high-quality research, CILE published a call-for-papers in both English and Arabic (https://www.cilecenter.org/en/news/call-for-papers-policies-regulations-and-bioethics-of-genomic-research/ ) and a Background Paper was drafted in order to streamline the discussions in the conference (https://www.cilecenter.org/en/wp-content/ uploads/2018/o1/Background-Paper-QGP-CILE-Conference-April-2018.pdf). 
The review of the discussions on genomics and Islamic ethics presented in this chapter illustrates that this was the case when the ethical aspects of the Human Genome Project (HGP) and genomics were discussed in the Muslim world. Scientists collaborated with Muslim religious scholars through a certain mechanism of collective and interdisciplinary reasoning rooted in the Islamic tradition, known as al-ijtihād al-jamā $\bar{\imath}$.

By addressing the ethical questions of genomics and related fields through the mechanism of al-ijtihād al-jama $\bar{\imath} \bar{l}$, both biomedical scientists and religious scholars could achieve together what each group could not have done alone. Within this interdisciplinary setting, Muslim religious scholars could develop a kind of scientific literacy about genomics and gain scientific information that they otherwise would not have access to. However, these interdisciplinary discussions were not without difficulties. Scientific information provided by biomedical scientists was not always clear enough or delivering the level of certainty that Muslim religious scholars were seeking. What must be done with such incomplete or indecisive information, especially when a rigorous benefit-risk assessment should be performed on cutting-edge technologies like those in the field of genetics and genomics? Where are the borderlines that should distinguish between the role to be played by the biomedical scientists and the one assigned to religious scholars? Whose opinion should weigh heavier when the two groups disagree with each other? These were some of the controversial questions that the contributors to these interdisciplinary deliberations had to grapple with. This chapter reviewed the various ways used by these participants to address such questions and highlighted the key agreements and disagreements. This study has also shown that the Islamic ethical deliberations had their own concerns, which we do not see, or at least do not occupy a central position, in parallel discussions in the West, e.g. the perceived separation between scientific research on one hand and religious guidance and associated values on the other. This made some religious scholars quite suspicious about the intentions, aims and long-term plans of scientific institutions based in the West and concurrently almost obsessed with the fear that the same separation can occur to scientific institutions (to be) based in the Muslim world. This point raises questions about the hypothetical universality of secular ethics and the conviction that non-religious ethics can speak for everybody, hence making it an integral part of the so-called public morality. These discussions showed that putting religious values aside when discussing the (un)ethical character of scientific research can be quite problematic for certain groups of people.

As for the overall position towards the Human Genome Project (HGP) and the field of genomics in general, the chapter analysed two main approaches. 
The precaution-inclined approach is leaned towards taking the "safe side" option by requesting to wait and taking time before rushing into joining the on-going scientific research ventures related to emerging fields like genetics and genomics. To be on the safe side, overall preference is given to considering all related activities as prohibited until this is proven otherwise. The embracement-inclined approach is more pre-emptive in nature, where the key governing idea is that Muslims should not remain idle anymore, and immediate pro-active steps must be taken to ensure that Muslim countries will make significant contributions to the on-going scientific revolution in these fields. A great deal of the chapter is dedicated to the detailed arguments and counterarguments of each approach. The study argues that the embracement-inclined approach proved to be more influential, both at the theoretical level of the ethical discourse and at the practical level of actual genomics initiatives, which took place in some Muslim countries.

Despite the various breakthroughs achieved by the interdisciplinary discussions reviewed in this chapter, these discussions have shown that there are serious challenges ahead. Generally speaking, there is a serious problem of pursuing the recent scientific updates in a rapidly growing field like genomics. The material presented in the conferences and expert meetings held in the 199os remained to be the only reference in all-subsequent discussions with hardly any significant updates, even after the completion of the HGP. With regard to the informative component of these discussions, which is usually assigned to the biomedical scientists, it is clear that more specialists in genetics and genomics should be involved. One would also add that papers submitted to these meetings and conferences should be solicited from geneticists with a good publication record in the field, not just those who can read works published by others and then translate them into Arabic. Additionally, the overall scientific literacy of religious scholars should improve, and they should not remain exclusively dependent on the papers submitted to each conference. As for the normative component which is generally entrusted to the religious scholars, much more rigorous tools should be developed to manage the benefit-risk assessment, even if no conclusive information is not available yet. The discussions reviewed in this chapter, and also elsewhere (Ghaly 2012, 190-191), demonstrate that religious scholars usually expect biomedical scientists to only come up with information that has been verified and consequently get recognized as certain and conclusive, otherwise this will not be part of proper science. This perception of science can be quite problematic, especially in fields like genomics and genetics. I would suggest addressing this problem by improving the literacy of religious scholars in philosophy of science in general and philosophy of medicine in particular. When it comes to clinical research, 
clinical medicine and therapeutic interventions in particular, philosophers of medicine indicate that uncertainty is unavoidable, with just a few exceptions like vaccination and antibiotics. The same holds true for preventive medicine where uncertainty proliferates and thus claims of certainty are often baseless. Bearing this mind, decisions and judgements in clinical medicine are usually based on plausibility more than on certainty. William Osler, the renowned Canadian physician known as the "Father of Modern Medicine", recognized this fact when he called medicine the art of probability and the science of uncertainty (Thompson and Upshur 2018, 3, 77, 122, 127, 138, 141, 144).

As for the contributors to these interdisciplinary discussions, only two groups still dominate the discussions, namely biomedical scientists and religious scholars. However, the complexity of the ethical dilemmas raised by fields like genomics and genetic engineering necessitate having various groups with much more diversified backgrounds. The group of religious scholars usually consists, dominantly or exclusively, of specialists in Islamic jurisprudence (figh); the so-called jurists $\left(f u q a h \bar{a}^{3}\right)$. However, the vast Islamic tradition cannot be reduced to the discipline of figh, despite its recognized significance in the Islamic bioethical discourse. The absence of specialists in Islamic theology and philosophy in the discussions reviewed in this chapter was reflected in the somehow poor and superficial discourse on the intersection between genomics and Islamic theology and philosophy. Serious ethical dilemmas with crucial theological and philosophical underpinnings were completely missing, including the very concept of soul and its possible relation with the genome. ${ }^{25}$ Surely, these interdisciplinary discussions would be much more enriched once the pool of participants get progressively diversified by adding specialists in other related fields depending on the topics to be addressed, e.g. social sciences, medical anthropology, secular bioethics, Jewish and Christian bioethics, medical law, etc. We hope that the material included in this volume will set the suitable base for filling some of the abovementioned gaps.

25 The background paper of the CILE seminar, organized on 3-5 April 2017, whose proceedings are published in this volume, outlined some of these issues and questions like: what makes us distinctively human? How to determine the boundaries between what is nor$\mathrm{mal} /$ natural and abnormal/unnatural? How should the controversy on determinism and free will be revisited in the age of genomics? (https://www.cilecenter.org/en/wp-content/ uploads/2016/o6/Genomics-Background-Paper-English.pdf). 


\section{References}

Abrahamov, Binyamin. 1989. "A Re-Examination of al-Ash'arī's Theory of Kasb According to Kitāb al-Luma”. The Journal of the Royal Asiatic Society of Great Britain and Ireland 2: 210-221.

Abū Ghudda, 'Abd al-Sattār. 1998. "Al-Muwākaba al-Shar'iyya li mu'țayāt al-handasa al-wirāthiyya". In Al-Wirātha wa al-handasa al-wirāthiyya wa al-jīnūm al-basharīwa al-'ilāj al-jīnī: Ru’ya Islāmiya, edited by Jundī, Aḥmad Rajā̄̄ì, 573-594. Kuwait: Islamic Organization for Medical Sciences.

Alahmad, Ghiath and Kris Dierickx. 2014. "Confidentiality, Informed Consent and Children's Participation in the Saudi Biobank Governance: A Comparative Study". Eastern Mediterranean Health Journal 20 (11): 681-689.

Alahmad, Ghiath, Mohammed Al Jumah and Kris Dierickx. 2015. Confidentiality, Informed Consent, and Children's Participation in Research Involving Stored Tissue Samples: Interviews with Medical Professionals from the Middle East". Narrative Inquiry in Bioethics 5(1): 53-66.

Al-Munażzama al-Islāmiyya li al-Tarbya wa al-'Ulūm wa al-Thaqāfa (Īsiskū). 1993. Al-In'ikāsāt al-akhlāqiyya li al-abhạth al-mutaqddima fì ilm al-wirātha. Rabat, Morocco: Islamic Educational, Scientific and Cultural Organization \& Tripoli, Libya: World Islamic Call Society.

Amīn, Ṭāhā. 2003. “Qirāa īmāniyya li al-jīnūm al-Basharī”. Al-Wa'y al-Islāmī 39 (447): 37-41.

Anees, Munawar. 1993. "Biological Sciences: Moral Mediators in the Making? In Islamic Educational, Scientific and Cultural Organization (ISESCO)". Ethical Implications of Modern Researches in Genetics, 77-88. Rabat, Morocco: Islamic Educational, Scientific and Cultural Organization \& Tripoli, Libya: World Islamic Call Society.

Ba'dānī, Muḥammad Nu'mān al-. 2016. Tabwīb qarārāt majma'ayy al-fiqh (al-dawlì wa al-rābița) ilā al-dawra al-thānya wa al-ishrīn. Available at http://www.saaid.net/ book/open.php?cat=4\&book=11261 retrieved on 26 May 2018.

Bār, Muḥammad 'Alī al-. 1998. "Naẓra fāḥiṣa lī al-fuhūṣāṭ al-țibbiya al-jīniyya (al-faḥṣ qabl al-zawāj wa al-istishāra al-wirāthiyya)". In Al-Wirātha wa al-handasa al-wirāthiyya wa al-jīnūm al-basharī wa al- ilāj al-jīnī: ru’ya Islāmiya., edited by Jundī, Aḥmad Rajā'ī, 621-662. Kuwait: Islamic Organization for Medical Sciences.

Boddington, Paula. 2012. Ethical Challenges in Genomics Research: A Guide to Understanding Ethics in Context. New York: Springer.

Collins, Francis. 2006. The Language of God:A Scientist Presents Evidence for Belief. New York: Free Press.

ELSI Research Planning and Evaluation Group. 2000. A Review and Analysis of the Ethical, Legal, and Social Implications (ELSI) Research Programs at the National Institutes of Health and the Department of Energy. Available at http://www.genome.gov/ 
Pages/Research/DER/ELSI/erpeg_report.pdf (retrieved on 25 May 2018)

Ghaly, Mohammed. 2010. Islam and Disability: Perspectives in Theology and Jurisprudence. London: Routledge.

Ghaly, Mohammed. 2012. "The Beginning of Human Life: Islamic Bioethical Perspectives". Zygon: Journal of Religion and Science 47 (1): 175-213.

Ghaly, Mohammed. 2015. "Biomedical Scientists as Co-Muftis: Their Contribution to Contemporary Islamic Bioethics". Die Welt des Islams 55: 286-311.

Ghaly, Mohammed. 2016. Genomics in the Gulf Region and Islamic Ethics: The Ethical Management of Incidental Findings. Doha, Qatar. based World Innovative Summit for Health (WISH). Available at http://www.wish.org.qa/wp-content/uploads/2018/o1/Islamic-Ethics-Report-EnglishFINAL.pdf, retrieved 28 May 2018.

Ghaly, Mohammed. 2016a. 'Ilm al-jīnūm fi mințaqat al-Khalīj: idārat al-natā'ij al-'aradiyya min manzūur Islāmī. Doha, Qatar: World Innovative Summit for Health (WISH). Available at http://www.wish.org.qa/wp-content/uploads/2018/o1/Islamic-Ethics-Report-Arabic.pdf, retrieved 28 May 2018.

Green, Eric, James Watson and Francis Collins. 2015. "Twenty-Five Years of Big Biology”. Nature 526: 29-31.

Ḥaffār, Sa'īd al-. 1993. "Al-In'ikāsāt al-qiyamiyya wa al-khlāqiyya wa al-qānūniyya wa al-insāniyya li abraz munjazāt al-thawra al-ihyyāiyya”. In Al-Munaẓẓama al-Islāmiyya li al-Tarbya wa al-'Ulūm wa al-Thaqāfa (Īsiskū) (1993). Al-In'ikāsāt al-akhlāqiyya li al-abhāth al-mutaqddima fì 'ilm al-wirātha, 123-139. Rabat, Morocco: Islamic Educational, Scientific and Cultural Organization \& Tripoli, Libya: World Islamic Call Society.

Hallaq, Wael. 1997. A History of Islamic Legal Theories: An Introduction to Sunni Ușūl Al-Fiqh. Cambridge: Cambridge University Press.

Ḥatḥūt, Ḥassān. 1998. "Qirāat al-jīnūm al-basharī". In Al-Wirātha wa al-handasa al-wirāthiyya wa al-jīnūm al-basharī wa al-îlāj al-jīnī: ru’ya Islāmiya., edited by Jundī, Aḥmad Rajā̄ī 273-286. Kuwait: Islamic Organization for Medical Sciences.

Ibn 'Abd al-Salām, al-Izz. 1991. Qawā'id al-aḥkām fì mașāliḥ al-anām. Edited by Ṭāhā 'Abd al-Ra'ūf Sa'd. Cairo: Maktabat al-Kulliyyāt al-Azhariyya.

Idrīs, 'Abd al-Fattāh. 2003. "Al-Amn al-mațlūb li al-kharīṭa al-jīniyya". Majallat al-Way al-Islāmī 40 (450): 22-25.

International Islamic Fiqh Academy (IIFA). 1998. Majallat Majma' al-Fiqh al-Islāmī, (11). Jeddah: International Islamic Fiqh Academy.

Islamic Educational, Scientific and Cultural Organization (ISESCO). 1993. Ethical Implications of Modern Researches in Genetics. Rabat, Morocco: Islamic Educational, Scientific and Cultural Organization \& Tripoli, Libya: World Islamic Call Society.

Jasanoff, Sheila. 2011. Reframing Rights: Bioconstitutionalism in the Genetic Age. Cambridge: Massachusetts Institute of Technology.

Jundī, Aḥmad al-.1998a. "Lamḥa ḥawla al-handasa al-wirāthiyya wa al-jīnūm al-basharī 
wa al-'ilāj al-jīnī: Ru'ya Islāmiyya". In Al-Wirātha wa al-handasa al-wirāthiyya wa aljīnūm al-basharīwa al-ilāj al-jīni: Ru'ya Islāmiya, edited by Jundī, Aḥmad Rajā̄ī, 233o. Kuwait: Islamic Organization for Medical Sciences.

Jundī, Aḥmad Rajā'ī. 1998. Al-Wirātha wa al-handasa al-wirāthiyya wa al-jīnūm albasharī wa al-ilāj al-jīnī: ru'ya Islāmiya. Kuwait: Islamic Organization for Medical Sciences.

Jundī, Aḥmad. 2013. "Al-Jīnūm al-Basharī min al-naẓariyya ilā al-taṭbīq". In Buhūth wa tawșiyyāt al-nadwa al- ilmiyya hawla al-wirātha wa al-handasa al-wirāthiyya wa aljīnūm al-basharī min manzūur Islāmī, edited by Abū 'Alyū, 14- 24. Jeddah: International Islamic Fiqh Academy. An online version can be accessed via https://www. imamu.edu.sa/elibrary/Documents/Genetic_Engineering.pdf (retrieved 21 June 2018)

Kan`ān, Aḥmad Muḥammad. 2003. "Al-Jīnūm al-basharī wa taqniyyāt al-handasa al-wirāthiyya: muqārabāt fiqhiyya”. Majallat al-Buhūth al-fiqhiyya al-Mu'āṣira 15 (6o): 68-101.

Kaye, Jane et al. 2012. "ELSI 2.o for Genomics and Society". Science 336: 673-674.

Khādimī, Nūr al-Dīn al-. 2003. "Al-Jīnūm al-basharī". Majallat al-Buhuūth al-fiqhiyya al-Mu'ạșira 15 (58): 7-48.

Khādimī, Nūr al-Dīn al-. 2004. "Al-Kharīṭa al-jīniyya al-bashariyya (al-jīnūm al-basharī): al-aḥkām al-Shar'iyya wa al-ḍawābiṭ al-akhlāqiyya". Majallat al-Mishkāh 2: 59-76.

Khādimī, Nūr al-Dīn al-. 2007. "Al-Ḍawābiṭ al-Shar'iyya li buhūth al-jīnūm al-basharī". A paper presented to the second conference on "Pan Arab Human Genetics" held in November 2007, available at http://www.cags.org.ae/e1khadami.pdf (Retrieved 20 June 2018).

Kulliyyat al-Sharī'a wa al-Qānūn. 2002. Al-Handasa al-wirāthiyya bayna al-Sharīa wa al-qānūn. Al-Ain, UAE: United Arab Emirates University.

Kurdī, Aḥmad al-Ḥājjī al-. 1998. "Al-Handasa al-wirāthiyya fī al-nabāt wa al-ḥayawān wa ḥukm al-Sharī‘a al-Islāmiyya fīhā". In Al-Wirātha wa al-handasa al-wirāthiyya wa al-jīnūm al-basharīwa al-'ilāj al-jīnī: ru’ya Islāmiya., edited by Jundī, Aḥmad Rajā̄ī, 229-242. Kuwait: Islamic Organization for Medical Sciences.

Maymān, Nāṣir al-. 1998. "Al-Irshād al-jīnī: ahammiyyatuh - āthāruh -mahādhīruh". In Al-Wirātha wa al-handasa al-wirāthiyya wa al-jīnūm al-basharì wa al-ilāj al-jīnī: Ru'ya Islāmiya, edited by Jundī, Aḥmad Rajāì̄, 797-824. Kuwait: Islamic Organization for Medical Sciences.

Morrison, Michael, Donna Dickenson and Sandra Soo-Jin Lee. 2016. Introduction to The Article Collection "Translation in Healthcare: Ethical, Legal, and Social Implications". BMC Medical Ethics 17 (74): 1-6.

Nashmī, 'Ajīl al-. 1998. Al-Wașf al-Shar'ì li al-jīnūm al-basharī wa al- ilājj al-jīnī. In Jundī, Aḥmad Rajā'ì (ed.) Al-Wirātha wa al-handasa al-wirāthiyya wa al-jīnūm al-basharī wa al- 'ilāj al-jīnī: ru'ya Islāmiya, 545-570. Kuwait: Islamic Organization for Medical 
Sciences.

Nasim, Anwar. 1993. "Genetic Manipulations and Ethical Issues: Challenges for the Muslim World. In Islamic Educational, Scientific and Cultural Organization (ISESCO)" Ethical Implications of Modern Researches in Genetics, 59-74. Rabat, Morocco: Islamic Educational, Scientific and Cultural Organization \& Tripoli, Libya: World Islamic Call Society.

Opwis, Felicitas. 2010. Mașlaha and the Purpose of the Law: Islamic Discourse on Legal Change from the 4th/1oth to 8th/14th Century. Leiden: Brill.

Qatar Biobank. 2014. A Healthier Future Starts with You. Doha: Qatar Biobank.

Rabinow, Paul, and Gaymon Bennett. 20og. "Synthetic Biology: Ethical Ramifications 2009". Systems and Synthetic Biology 3 (1-4): 99-108.

Raysūnī, Aḥmad al-. 2010. Abḥāth fi al-maydān. Cairo: Dār al-Kalima li al-Nashr wa al-Tawzī́.

Rizq, Hānī. 2003. Mūjaz tārīkh al-kawn: min al-infijār al-'azìm ilā al-istinsākh al-basharī. Damascus: Dār al-Fikr.

Rizq, Hānī. 2007. Al-Jīnūm al-basharī wa akhlāqiyyātuh. Damascus: Dār al-Fikr.

Rūkī, Muḥammad al-. 1998. "Al-Istifāda min al-handasa al-wirāthiyya fī al-ḥayawān wa al-nabāt wa ḍawābițuhā al-Shar'iyya”. In Al-Wirātha wa al-handasa al-wirāthiyya wa al-jīnūm al-basharī wa al-'ilāj al-jīnī: ru’ya Islāmiya, edited by Jundī, Aḥmad Rajā'̄̄, 211-225. Kuwait: Islamic Organization for Medical Sciences.

Thompson, R. Paul and Ross E. Upshur. 2018. Philosophy of Medicine: An Introduction. New York: Routledge.

Thorpe, Charles. 2006. Oppenheimer: The Tragic Intellect. Chicago: The University of Chicago Press.

'Uthmān, Muhammad Ra'fat. 20og. Al-Mādda al-wirāthiyya: al-jīnūm. Cairo: Maktabat Wahba.

Willyard, Cassandra. 2018. Expanded Human Gene Tally Reignites Debate. Nature vol. 558: 354-355.

Wizārat al-Awqāf wa al-Shu'ūn al-Islāmiyya bi al-Kuwayt. 1983-2006. Al-Mawsū'a al-fiqhiyya. Kuwait: Ministry of Endowments and Islamic Affairs.

Zuhaylī, Muḥammad al-. 1998. Al-Irshād al-jīnī. In Al-Wirātha wa al-handasa al-wirāthiyya wa al-jīnūm al-basharī wa al-ilā̄j al-jīnī: ru'ya Islāmiya, edited by Jundī, Aḥmad Rajā̄ī, 773-793. Kuwait: Islamic Organization for Medical Sciences. 